\title{
ANDRZEJ POTOCKI \\ Między szkołą i parafią. W kierunku katechezy sakramentalnej
}

Wydawało się, że dylematy organizacyjnego usytuowania katechezy były dylematami najwcześniejszych lat 90. Mówiliśmy wówczas o powrocie religii bądź katechezy do szkoły; niektórzy - przywiązujący mniejszą wagę do perspektywy historycznej - o wprowadzeniu religii do szkoły. I to zdawało się definiować nowość sytuacji. Brzmiało to jak pewnik: miejscem jest odtąd szkoła, a to, co tam się oferuje, to katecheza. Sytuacja miała być klarowna ${ }^{1}$. Co więcej, z biegiem lat można byłoby przypuszczać, że skoro kolejne roczniki dzieci i młodzieży, ale i katechetów, będą religijnie dojrzewać już w nowym klimacie, zaproponowany w 1990 r. kształt szkolnej i katechetycznej zarazem posługi Kościoła będzie się stawał naturalny i oczywisty. Po z górą 20 latach widać, że takim nie jest ${ }^{2}$.

Względnie szybko zorientowaliśmy się, że w szkole nie zrealizujemy wszystkich spośród założonych w dokumentach katechetycznych zasadniczych celów katechezy. Stwierdzono to u nas oficjalnie: szkolne nauczanie religii nie wydaje się (...) wypetniać w zadawalajacym stopniu wszystkich założeń integral-

Andrzej P O T O C K I OP, prof. dr hab., profesor zwyczajny w Instytucie Profilaktyki Społecznej i Resocjalizacji Uniwersytetu Warszawskiego oraz w Instytucie Filozofii i Socjologii Akademii Pedagogiki Specjalnej im. Marii Grzegorzewskiej w Warszawie, Warszawa, e-mail: a.potocki@uw.edu.pl

${ }^{1} \mathrm{O}$ charakterze oferty Kościoła na terenie szkoły zob. więcej np.: K. M i s i a s z e k: Koncepcja nauczania religii katolickiej w publicznej szkole polskiej. Próba oceny. Warszawa 2010; K. N y c z: Szkoła miejscem katechezy. W: Przestanie dokumentów katechetycznych Kościoła w Polsce. Red. S. D z i e k o ń s k i. Warszawa 2003 s. 13-22.

${ }^{2} \mathrm{O}$ bilansie 20-lecia zob. np. S. D z i e k o ń s k i: Dwadzieścia lat katechezy w szkole. „Katecheta”. R. 2010 nr 1. Por. J. K r a s z e w s k i: Po dziesięciu latach katechezy w szkole. „Katecheta”. R. $2000 \mathrm{nr} 6$. 
nie ujmowanej katechezy (PDK, n. 13³). Stąd zaczęliśmy mówić o potrzebie uzupełnienia tego, co dajemy w szkole, tym, co możemy dać w parafii. Mówiły o tym autorytety. Jan Paweł II, przemawiając do biskupów polskich z okazji ich wizyty ad limina, wskazał w 1993 r. i powtórzył pięć lat później, że katechizacja w szkole domaga się oczywiście uzupetnienia o wymiar parafialny duszpasterstwa dzieci i młodzieży. Podobnie i nasi poważni katechetycy: Dzisiaj widzimy wyraźnie, że na katechezie szkolnej poprzestać nie możemy, ale musimy ja uzupetniać i dopetniać katecheza parafialna ${ }^{5}$. Termin ,uzupełnianie”, ale i myślenie o uzupełnianiu szkoły przez parafię, wchodziły do obiegu. Dziś - na tle doświadczeń lat minionych i wciąż pogłębianej refleksji - nie do końca to przekonuje. Co więcej, chciałoby się ów porządek myślenia odwrócić. Katecheza ma być dziełem wspólnoty chrześcijańskiej, podmiotem katechetycznej posługi jest w istocie Kościół, zaś szkoła może jedynie we właściwy sobie sposób wspomagać Kościół, podejmując się realizacji dostępnych dla siebie zadań katechetycznych ${ }^{6}$. Zatem to nie parafia ma pomagać szkole, uzupełniając jej działania, ale to szkoła ma wspomagać parafię jako właściwy podmiot katechezy. To jest teza, którą autor stawia i wokół której spróbuje zorganizować dalsze rozważania.

Owszem, lansowanie tej tezy może nie być popularne tak wśród kadry katechetycznej, jak rodziców. Kadra oswoiła się już z modelem: w szkole lekcje religii, zaś w parafii przygotowanie do sakramentów, bo szkoła tego do końca nie załatwi. Uznaliśmy to za rozwiązanie optymalne. Rewolucja w myśleniu nie jest tu potrzebna. Wystarczy korekta: w parafii przygotowujemy do sakramentów nie dlatego, że „szkoła tego nie załatwi”, ale dlatego, że katecheza sakramentalna winna być istotowo związana z życiem wspólnoty chrześcijańskiej zorganizowanej wokół celebracji sakramentów Kościoła. Korekta myślenia rodziców może być bardziej kłopotliwa. Racje pragmatyczne bowiem - szczególnie te zauważane przez rodziców - zdają się przemawiać za ulokowaniem całości formacji religijnej młodego pokolenia w szkole. To dla rodziców z pewnością wygodniejsze. Jednakże wypada formować rodziców w kierunku rozumienia roli, znaczenia parafii jako właściwego miejsca dla przeżycia przez ich dziecko wtajemniczenia chrześcijańskiego.

\footnotetext{
${ }^{3}$ Konferencja Episkopatu Polski: Dyrektorium katechetyczne Kościoła katolickiego w Polsce (przyjęte 20.06.2001). Kraków 2001 [dalej: PDK].

${ }^{4}$ J a n P a w e 1 I I: Program dla Kościoła w Polsce. Kraków 1998 s. 35.

${ }^{5}$ J. K r a s z e w s ki: Wtajemniczenie w historie zbawienia - klasy IV-VI. W: Katecheza w parafii. Poszukiwanie tożsamości. Red. K. K a n t o w s k i. Warszawa 2004 s. 47.

${ }^{6}$ Por. K. M i s i a s z e k: Wspólnota chrześcijańska (parafia) jako podmiot katechezy. W: Katecheza $w$ parafii, dz. cyt., s. 24.
} 


\section{Dylematy miejsca}

Dobrze będzie sięgnąć do wyników badań sondażowych CBOS, w których pytano respondentów (ogólnopolska próba reprezentatywna, badania 69.06.2008 r.): „Czy Pana(i) zdaniem religia powinna być nauczana w szkołach publicznych czy też nie?” Odpowiedź „tak” dało 65\%, ,nie” $32 \%$ indagowanych ${ }^{7}$. Jak widać, Polacy w większości akceptują obecność religii w szkole, choć w stosunku do 2007 r., gdy robiono podobne badania ${ }^{8}$, aprobata spadła aż o $7 \%$. Jest i tak wyraźnie wyższa od tej, którą notowano w początkach obecności religii w szkole. We wrześniu $1991 \mathrm{r}$. wynosiła 57\%. Według ostatnich badań religii w szkole nie aprobowała niemal jedna trzecia badanych (32\%), w 1991 r. wyraźnie więcej $(42 \%)^{9}$.

$\mathrm{Z}$ chwila powrotu religii do szkoły to ta dla wielu młodych ludzi stała się faktycznie miejscem inicjacji religijnej, choć przestrzenią dla tej inicjacji podstawową winny być - co oczywiste - rodzina i parafia. Te są poniekąd naturalnymi, podstawowymi miejscami katechezy. Tam katecheza być musi. W szkole nie musi. Szkoła bowiem nie jest programowo podmiotem katechezy, nie ma charakteru eklezjalnego. Jednakże to, że w szkole katecheza być nie musi, nie oznacza, że katechezy w szkole ma nie być.

Rozwińmy myśl o podmiocie katechezy ${ }^{10}$. Zrobimy to w trzech krokach, dotykając triady: wspólnota chrześcijańska, Kościół i parafia. Pomagają w tym dokumenty katechetyczne Kościoła akcentujące znaczenie wspólnoty chrześcijańskiej dysponującej odpowiednimi środkami potrzebnymi dla zainicjowania i rozwoju wiary. Dyrektorium Kościoła katolickiego stwierdza: za katecheze jest odpowiedzialna cała wspólnota chrześcijańska (DOK, n. 22011). Podobnie polskie dyrektorium (PDK, n. 120). To wspólnota chrześcijańska jest początkiem, miejscem i celem katechezy. Środowiskiem katechetycznym w ścisłym sensie jest wspólnota żyjąca wiarą (DOK, n. 254). Jest zrozumiałe, że w rzeczywistość wiary wypada wchodzić wśród wierzących, a modlitwy uczyć się z modlącymi. Co więcej, wspólnota chrześcijańska jest w sobie samej żywą katecheza. Przez to, czym ona jest, co głosi, co celebruje i co czyni, pozostaje zawsze żywym, nieo-

\footnotetext{
${ }^{7}$ Centrum Badania Opinii Społecznej (CBOS): Religia w systemie edukacji. Komunikat z badań BS/136/2008. Warszawa 2008.

${ }^{8}$ Centrum Badania Opinii Społecznej (CBOS): Opinie o nauczaniu religii. Komunikat z badań BS/119/2007. Warszawa 2007.

${ }^{9}$ Centrum Badania Opinii Społecznej (CBOS): Religia w systemie edukacji, dz. cyt.

${ }^{10} \mathrm{O}$ podmiocie katechezy zob. np. H. I w a $\mathrm{n}$ i u k: Nauka religii $w$ szkole a katecheza parafialna. „Ateneum Kapłańskie”. T. 142: 2004 z. 571; M. M a j e w s k i: Szkoła podmiotem uczenia religii i katechezy. W: Katechizacja $w$ szkole. Red. M. M a je w s k i. Lublin 1992 s. 45-55; A. P o t o c k i: Parafia podmiotem i miejscem katechezy. „Perspectiva”. R. 5: 2006 nr 2.

${ }^{11}$ Kongregacja ds. Duchowieństwa: Dyrektorium ogólne o katechizacji (15.08.1997). Pallottinum 1998 [dalej: DOK].
} 
dzownym i pierwszorzędnym miejscem katechezy (DOK, n. 141). Tak, pierwszym katechetą jest przede wszystkim wspólnota chrześcijańska rozumiana jako podmiot solidarnie odpowiedzialny za katecheze $e^{12}$.

Wspólnotą chrześcijańską jest dla nas Kościół, stąd katecheza jest ze swej istoty aktem eklezjalnym (DOK, n. 78). Domaga sie przede wszystkim uznania Kościoła jako jej prawdziwego podmiotu, gdyż to on jest rzeczywistym nauczycielem wiary (PDK, n. 13). Katecheza jest nie tylko przez Kościół prowadzona, nie tylko o Kościele uczy, ale stanowi też przestrzeń doświadczania Kościoła. Dlatego tak ważne jest, by przestrzeń ta była właściwie ukształtowana. Można bowiem wyobrazić sobie tak dobre, jak i nienajlepsze funkcjonowanie tej przestrzeni. Odpowiednio: dobre lub złe warunki do spotkania się młodego człowieka z Kościołem ${ }^{13}$. Katecheza ma budować przekonujący, zachęcający obraz Kościoła. Taki, dla którego katechizowany chciałby z nim się identyfikować. Tymczasem, jeśli w niedzielnej mszy świętej uczestniczy dziś ok. 30\% młodych ludzi, a z katechezy korzysta 70-90\%, to widać, że katecheza nie do końca prowadzi do pełnego zaangażowania w życie Kościoła.

W trzecim z zapowiadanych kroków dochodzimy do parafii. To Kościół jako fakt, doświadczenie najbliższej katechizowanemu wspólnoty chrześcijańskiej. Dokumenty Kościoła nie pozostawiają wątpliwości. Jan Paweł II w adhortacji Catechesi tradendae: Chociaż prawdą jest, że katecheza może być wszędzie prowadzona, to jednak musze podkreślić - zgodnie z życzeniami wielu biskupów ze wspólnota parafialna, jako zajmująca szczególne miejsce, powinna pozostać krzewicielka i inspiratorka katechezy (CT, n. $\left.67^{14}\right)$. Winna być zwyczajnym środowiskiem, $w$ którym rodzi się $i$ wzrasta wiara (DOK, n. 257). Parafia jest (...) podstawowym miejscem katechezy dzieci i rodziców (KKK, n. $2226^{15}$ ). Jest środowiskiem katechetycznym już przez to, że stanowi wspólnotę wiary, modlitwy, chrześcijańskiej miłości. Owszem, wokół nauczania religii w polskiej szkole w ciągu ostatnich dwóch dekad skupiała się energia naszych katechetyków i katechetów. To ze względu na duże znaczenie katechezy w szkole katecheza na terenie parafii wyraźnie zeszła na drugi plan. Tymczasem - jak widzieliśmy - dokumenty katechetyczne podnoszą jej wybitnie formacyjną misję.

${ }^{12}$ E. A l b e ri ch: Katecheza dzisiaj. Podręcznik katechetyki fundamentalnej. Warszawa 2003 s. 236.

${ }^{13}$ Zob. wyniki badań autora na ten temat: A. P o t o c k i: Dlaczego młodzież boi się Kościoła? W: Religijna i moralna kondycja młodzieży polskiej. Mity i rzeczywistość. „Socjologia Religii”. T. 3. Red. J. B a n i a k. Poznań 2005 s. 183-200. Por. Katecheza w Kościele i dla Kościota. Red. R. C z e k a 1 s k i. Płock 2006.

${ }^{14}$ J a n P a w e 1 I I: Adhortacja apostolska Catechesi tradendae (16.10.1979). W: Katecheza po Soborze Watykańskim II w świetle dokumentów Kościoła. Red. W. Ku b i k. T. 2. Warszawa 1985 s. 146-217 [dalej: CT].

${ }^{15}$ Katechizm Kościoła katolickiego (8.12.1992). Poznań 1994 [dalej: KKK]. 
Pożyteczny jest akcent położony przez dyrektorium polskie: parafia jest przede wszystkim uprzywilejowanym miejscem dla katechezy przygotowujacej do przyjmowania sakramentów świętych (PDK, n. 107). Mimo nauczania religii w szkole przygotowanie do przyjęcia sakramentów inicjacji chrześcijańskiej pozostało zadaniem parafii. Ta musi odnaleźć na nowo swoje powołanie (CT, n. 67). Oczywiście nieodzowne są intensywne starania na rzecz zintegrowania działań parafii i szkoły wokół potrzeb dzieci i młodzieży. Żadną miarą nie można obu tych instytucji sobie przeciwstawiać; zwłaszcza, że przy obecnym modelu nauczania religii Kościół działa jednocześnie w parafii i w szkole - przez parafię i przez szkołę. Zarówno w parafii, jak w szkole, oczekuje się katechezy, choć z inaczej rozłożonymi akcentami jeśli chodzi o cele zajęć oraz ich treści programowe. Wolno sądzić, że w parafii łatwiej niż w warunkach szkolnych zrealizować oczekiwania adhortacji Catechesi tradendae mówiącej, że celem katechezy, do którego winna ona zmierzać, jest rozwinięcie z pomoca Boża wiary dotad poczatkowej, doprowadzenie do petni i codzienne zasilanie życia chrześcijańskiego (n. 20). Co więcej, katecheza z natury swej jest zwiazana z catym sprawowaniem liturgii i sakramentów, gdyż wtaśnie w sakramentach, a zwłaszcza $w$ Eucharystii, Jezus Chrystus działa najpetniej w celu przemiany człowieka (n. 23).

\section{Dylematy treści}

Konstatacja podstawowa: w polskim, szkolnym systemie lekcji religii odbywa się - i ma się odbywać - faktycznie katecheza. Przecież do szkoły praktycznie przeniesiono katechezę w jej dotychczasowym, to jest parafialnym, kształcie programowym. Bo ten był wypracowany, gotowy, sprawdzony. Ale sprawdzony w parafii. W szkole miał się dopiero sprawdzać. To, co pojawiło się w szkole, miało respektować kościelną, zatem określoną przez Magisterium, wizję katechezy. Jako wkomponowane w życie szkoły zajęcia katechetyczne miały jednocześnie respektować organizacyjne wymagania tej ostatniej, korzystając wszak z oczywistego prawa do autonomii wedle ustaleń między Kościołem i państwem; choćby w zakresie programów nauczania i pomocy dydaktycznych niepodlegających zatwierdzeniu przez instytucje oświatowe.

Po latach skutki przeniesienia nauczania religii do szkoły są dobrze widoczne. W odniesieniu do dzieci i młodzieży wyraźny jest spadek udziału w niedzielnej mszy św. i regularnym przystępowaniu do sakramentów, a także słabsze zaangażowanie w pracę zespołów religijnych. Widać, że katecheza w szkole nie tylko nie wprowadza skutecznie $\mathrm{w}$ doświadczenie uczestnictwa w parafialnej wspólnocie, ale - zdarza się - izoluje od parafii. Dla wielu stwarza namiastkę życia religijnego, zaspokaja elementarne tak zwane potrzeby religijne, a w konsekwencji może i zastępuje parafię. Trzeba to uznać za oczywiste symptomy osłabienia więzi z parafią. Szkoła zatem nie formuje religijnie w pełnym wymiarze tego określenia, bo po prostu - ze względu na swój charakter i podstawowe 
cele - zrobić tego nie jest w stanie. Krótko mówiąc, nauka religii w szkole nie jest równoznaczna z pełnym pogłębianiem religijnej formacji młodych ludzi.

W świetle tego, co wyżej, staje teraz pytanie o optymalny kształt szkolnych zajęć z religii. Rewolucji tutaj, jak wiadomo, się nie przewiduje. Co jednak robić, by obecność religii w szkole była dla niej - a zwłaszcza dla uczniów - pożyteczna? Otóż nawet przy utrzymaniu w szkole zajęć o charakterze katechetycznym, a nie redukowaniu ich do lekcji religii, należy nadawać im wymiar kulturowy, zatem nie izolować treści programowych katechezy od treści programowych innych przedmiotów, zwłaszcza humanistycznych. Co więcej, winno nam zależeć na dobrej integracji katechezy z różnymi przedmiotami szkolnymi. W tym zresztą widzieć wypada szansę na zręczne wkomponowanie się katechezy w całe życie szkoły. Ważne jest poszukiwanie płaszczyzn owej integracji. Wypada zatem mniej akcentować to, co katechezę od innych przedmiotów dzieli, niż to, co katechezę z innymi przedmiotami łączy. Akcentując nadmiernie różnice, będziemy zmarginalizowani. Może wówczas niebezpiecznie zwiększać się dystans nie tylko między katechezą a innymi przedmiotami, ale także - w konsekwencji - dystans między wiarą a nauką, może i między wiarą a życiem. Nie należy przy tym zapominać, że szkolny związek religii z innymi przedmiotami jest uprawomocniony w kontekście wielowiekowego związku chrześcijaństwa z kulturą polską. Wszak nie da się poznać naszej kultury bez szerokiego przedstawienia jej zakorzenienia w chrześcijaństwie. Wszak nie da się doświadczyć chrześcijaństwa bez jego oglądu w ramach kultury.

Jak wcześniej nie bez racji mówiliśmy o dylematach miejsca katechezy (parafia czy szkoła), tak teraz przyznajmy, iż dylematy dotyczyć też mogą charakteru zajęć. Dyskusję katechetyków związaną z dylematem katecheza czy lekcja religii zauważmy, bo istotna, ale i odłóżmy ją na bok ${ }^{16}$. Ważniejsze - a pewnie i bardziej niepokojące - są preferencje Polaków dotyczące treści programowych szkolnych zajęć z religii. Otóż w trakcie wspominanych już badań CBOS z 2008 r. aż 58\% respondentów wskazało, że w ramach lekcji religii powinno się przekazywać głównie „wiedzę o różnych religiach i wierzeniach”, zaś 36\% opowiedziało się za przekazywaniem głównie wiedzy o zasadach religii katolickiej. Trudno nie skomentować uwagą o słabym rozumieniu przez badanych katechetycznego charakteru szkolnych zajęć z religii. Co więcej, odnosi się wrażenie, że większość preferuje model edukacji o charakterze religioznawczym. Tak mniej lub bardziej świadomie podważa się sens posługi Kościoła na terenie szkoły. Wszak dla zajęć z religioznawstwa Kościół nie jest potrzebny. Przypomina się

${ }^{16}$ Więcej zob. np. R. Chału p n i k: »Katecheza« czy »nauczanie religii«? W obronie szkolnej katechezy. „Katecheta”. R. 2000 nr 5; M. M a j e w s k i: Lekcja religii a katecheza. W: Katechizacja w szkole, dz. cyt., s. 57-66; J. S t r o b a: Od nauki religii do katechezy. W: Katecheza w szkole. Red. J. K r u c in a. Wrocław 1992 s. 17-24; P. T o m a s i k: Katechetyczny charakter lekcji religii. „Katecheta”. R. $2000 \mathrm{nr} 7-8$. 
niechlubnej pamięci marksistowskie religioznawstwo wprowadzane do naszych szkół średnich (szczęśliwie na krótko) od 1986 roku ${ }^{17}$. Zapytano też, który z dwóch wymiarów - kształtowanie wiary czy przekazywanie wiedzy - powinien, zdaniem respondentów, przeważać i stanowić zasadniczą treść szkolnych zajęć z religii. Jak się okazało, prawie dwie trzecie (64\%) było zdania, że lekcje mają służyć przede wszystkim przekazywaniu wiedzy, a blisko jedna trzecia badanych (30\%) wyraziła opinię, iż głównym celem lekcji jest kształtowanie wiary uczniów.

\section{W kierunku katechezy sakramentalnej}

Wprowadzenie w chrześcijaństwo to inicjacja. Służą jej sakramenty wtajemniczenia: chrzest, bierzmowanie i Eucharystia. Przypomina się kapitalne sformułowanie Vaticanum II: Kościót aktualizuje sie przez sakramenty $i$ przez cnoty $\left(\mathrm{LG}, \mathrm{n} .11^{18}\right)$. Katechizm Kościoła katolickiego dopowie: Sakramenty godnie celebrowane $w$ wierze udzielaja taski, która oznaczaja. Sa one skuteczne, ponieważ działa w nich sam Chrystus (KKK, n. 1127). Do życia sakramentalnego trzeba przygotowywać. Tradycyjnie, faktycznie od początków Kościoła wtajemniczeniu chrześcijańskiemu służyła katecheza ${ }^{19}$. To zachowało aktualność. Inicjacja należy do podstawowych funkcji katechezy ${ }^{20}$. Katecheza wtajemniczająca jest działaniem podstawowym $i$ fundamentalnym, $i$ to $w$ różnych wymiarach $i$ płaszczyznach (DOK, n. 63). Katecheza stanowi podstawowy element wtajemniczenia chrześcijańskiego, co urzeczywistnia się najbardziej i najskuteczniej w parafii (PDK, n. 13). Dokonuje się najpełniej w tej wspólnocie, która wiarę wyznaje, celebruje i potwierdza miłością (DOK, n. 68). Katechizować można wszystkich tym zainteresowanych. Ale sakramenty można udzielać jedynie wierzącym. Stąd zasadność przygotowywania do życia sakramentalnego we wspólnocie wiary - w parafii. Dziś wtajemniczenie jest przesłonięte szkolnym nauczaniem religii, stąd szkoła okazuje się wiodącą w kształtowaniu świadomości religijnej. Nie jest to, przyznajmy, rozwiązanie najszczęśliwsze.

\footnotetext{
${ }^{17}$ Więcej o tym zob. A. P o to c ki: Religioznawstwo w szkolnym wymiarze, „Communio. Międzynarodowy Przegląd Teologiczny”. R. 8: 1988 nr 4 s. 112-132.

18 Sobór Watykański II: Konstytucja dogmatyczna o Kościele »Lumen gentium « (21.11.1964). W: Sobór Watykański II. Konstytucje. Dekrety. Deklaracje. Poznań 1968 s. 146-257.

${ }^{19} \mathrm{O}$ chrześcijańskim wtajemniczeniu zob. E. B u l a n d a: Wtajemniczenie chrześsijańskie. „Ateneum Kapłańskie”. T 68: 1965 z. 338; Cz. K r a k o w i a k: Liturgia chrześcijańskiego wtajemniczenia dorostych. „Collectanea Theologica”. A. 40: 1990 fasc. 3; T e n ż e: Z teologii wtajemniczenia chrześcijańskiego. „Ruch Biblijny i Liturgiczny”. R. 45: 1992 nr 2-6; B. M o k r z y c k i: Sakramenty wtajemniczenia chrześcijańskiego. Warszawa 1981.

${ }^{20}$ E. M ł y ń s k a: Inicjacja do sakramentu Eucharystii i Pokuty klasy I-III. W: Katecheza w parafii, dz. cyt., s. 28.
} 
Teologowie akcentują cztery wymiary wtajemniczenia chrześcijańskiego: historiozbawczy, chrystologiczny, pneumatologiczny i eklezjalny ${ }^{21}$. Cechy katechezy wtajemniczającej podaje Dyrektorium ogólne o katechizacji (n. 67) ${ }^{22}$. Bada się funkcję wtajemniczenia w katechezie ${ }^{23}$. Nie mamy warunków, by wchodzić tu w szczegóły. Jeśli ich dotkniemy, to przy okazji oglądu katechezy związanej z poszczególnymi sakramentami.

Charakter katechezy przygotowującej do sakramentu chrztu związany jest przede wszystkim - co oczywiste - $\mathrm{z}$ wiekiem chrzczonej osoby. W przypadku małych dzieci właściwymi adresatami katechezy stają się rodzice: naturalni i chrzestni. W przypadku dorosłych adresatami są kandydaci do chrztu zapraszani do katechumenatu przedchrzcielnego prowadzonego stosownie do potrzeb i możliwości kandydata, a już uwzględniającego celowość jego włączenia w działalność parafii. Zatem w obu sytuacjach prowadzi się tu katechezę dorosłych. Ta ostatnia pojawia się także w odniesieniu do rodziców dzieci przygotowujących się do pierwszej Komunii św. To ważna okazja dla katechezy sakramentalnej; wyraźnie sprzyjająca tej katechezie. Istotne, by nadawać jej charakter bardziej wtajemniczający niż organizacyjny. W okresie po pierwszej Komunii św. chciałoby się widzieć spotkania rodziców stanowiące cykl katechez mistagogicznych, prowadzących do aktywnego i pełnego zaangażowania w Eucharystię. Specjalny projekt katechez parafialnych - umiejętnie skorelowany z programem katechezy w szkole - winien być adresowany do dzieci ${ }^{24}$. W efekcie przygotowanie do pierwszej Komunii św. może dobrze służyć integracji zaangażowanych tu środowisk: parafii, rodziny i szkoły.

Z pewnością najwięcej - jak dotąd - ma do powiedzenia katecheza parafialna adresowana do młodzieży przygotowującej się do sakramentu bierzmowania, sakramentu dojrzałości chrześcijańskiej (KKK, n. 1308). Środowisko, miejsce, osoby, formy przygotowania do bierzmowania określa Dyrektorium katechetyczne Kościoła katolickiego w Polsce (n. 107). Istotne jest rozróżnienie przygotowania dalszego, bliższego i bezpośredniego ${ }^{25}$. Przygotowanie dalsze odbywa się $\mathrm{w}$ ramach katechezy w szkole, bliższe już w parafii i to w parafii zamieszkania

${ }^{21} \mathrm{C} . \mathrm{K}$ r a k o w i a k: Z teologii wtajemniczenia chrześcijańskiego, dz. cyt.

${ }^{22}$ Streszcza je E. M ł y ń s k a,: Inicjacja do sakramentu Eucharystii i pokuty, dz. cyt., s. 29.

${ }^{23}$ J. S z p e t: Inicjacyjna funkcja katechezy. „Horyzonty Wiary”. R. 7: $1996 \mathrm{nr} 3$.

${ }^{24}$ Program taki przedstawia E. Młyńska: Inicjacja do sakramentu Eucharystii i Pokuty, dz. cyt., s. 38nn. Pokazuje sposób skorelowania i proponowane tematy katechez.

${ }^{25}$ Jego program omawia P. M ą k o s a: Katecheza inicjacyjna $w$ procesie przygotowania bliższego i bezpośredniego do sakramentu bierzmowania. W: Funkcja inicjacyjna katechezy w Kościele wspótczesnym. Red. K. K a n t o w s ki. Szczecin 2007 s. 172. Autor pisze o bierzmowaniu jako sakramencie inicjacji chrześcijańskiej i o katechetycznym przygotowaniu do bierzmowania. 
kandydata $^{26}$. Ma trwać trzy lata i pokrywać się z okresem nauki młodzieży w gimnazjum. Treści tej parafialnej katechezy sakramentalnej winny być korelowane w treściami nauki religii $\mathrm{w}$ szkole, metody wyraźnie odmienne. Jeszcze do nich wrócimy.

\section{Liturgiczny i wspólnotowy charakter katechezy sakramentalnej}

Punktując niedostatki katechezy w szkole, zwykliśmy akcentować zwłaszcza dwie kwestie. Pierwszą są daleko idące trudności z wprowadzeniem uczniów w życie sakramentalne, drugą podobne trudności z wprowadzeniem ich we wspólnotę Kościoła. Wydaje się, że katecheza sakramentalna, dzięki swemu inicjacyjnemu charakterowi, może podjąć trud zaradzenia owym niedostatkom.

Spotkania w ramach katechezy sakramentalnej iść powinny bardziej w kierunku celebracji niż lekcji religii (PDK, n. 107). Celebracje liturgiczne winny być właściwą dla katechezy sakramentalnej metodą (DOK, n. 30). Akcentował Jan Paweł II: Katecheza z natury swej jest zwiazana $z$ catym sprawowaniem liturgii $i$ sakramentów, gdyż wtaśnie w sakramentach, a zwłaszcza w Eucharystii, Jezus Chrystus działa najpetniej $w$ celu przemiany człowieka $(\mathrm{CT}, \mathrm{n} .23)^{27}$. Wypada zatem - szczególnie w katechezie parafialnej związanej z bierzmowaniem - unikać metod właściwych szkolnym lekcjom religii; zwłaszcza dydaktyzmu nastawionego na formację intelektualną. Spotkaniom przygotowującym do bierzmowania - choć nie tracą wymiaru katechetycznego - należy nadawać charakter modlitewno-celebracyjny. Ważne są spotkania modlitewne, nocne czuwania, rekolekcje, pielgrzymki, wyjazdowe dni skupienia (najlepiej na początek i na koniec okresu formacji). Nie można robić z tych spotkań lekcji religii na wzór szkolny, choćby dla uzupełnienia niedostatków szkolnej nauki. Winny dawać okazję do rozmów na tematy wiary i życia chrześcijańskiego, organizować dialog młodzieży i duszpasterza. Na znaczeniu winny tu zyskać metody liturgiczne i biblijne, a w ich ramach obok celebracji kursy biblijne, lectio divina. Celem ma być tutaj budowanie osobistej więzi z Chrystusem. Tak katecheza parafialna staje się w istotnej mierze katechezą liturgiczną.

Niezdolność katechezy w szkole do wprowadzenia młodego człowieka we wspólnotę Kościoła też jest zrozumiała. Tym bardziej jawi się pole dla katechezy sakramentalnej. Warunkiem jest jednak to, by odbywała się faktycznie we wspólnocie Kościoła i to w parafii katechizowanego. Taka katecheza pozwala

${ }^{26}$ T. P a n u ś: Parafia uprzywilejowanym miejscem dla katechezy przygotowujacej do sakramentu dojrzatości chrześcijańskiej. Doświadczenia krakowskie. W: Dzisiejszy bierzmowany. Problemy $i$ wyzwania. Red. J. S t a 1 a. Kielce 2005 s. 261.

${ }^{27}$ Por. H. I w a n i u k: Liturgia w katechezie parafialnej i szkolnej nauce religii. „Katecheta”. R. $2002 \mathrm{nr} 4$. 
poznać Kościół i stopniowo włączać się w jego życie. Dla włączenia w Kościół znaczenie podstawowe ma chrzest, ale współcześnie z oczywistych względów katecheza chrzcielna ma w praktyce katechetyczno-duszpasterskiej dość ograniczone rozmiary. W Kościół, zwłaszcza postrzegany jako zgromadzenie Eucharystyczne, włącza pierwsza Komunia św., stąd na katechezie komunijnej ciąży obok perspektywy sakramentalnej - także perspektywa akcentowania wspólnoty. $\mathrm{W}$ najszerszym wymiarze to ostatnie zadanie jest wszak do podjęcia w ramach katechezy przed bierzmowaniem. To w istotnej mierze ma być katecheza o Kościele, wtajemniczenie w misterium Kościoła. Wprowadzenie w życie własnej parafii i wielowymiarowość jej struktury.

W toku parafialnego przygotowania do bierzmowania nieodzowna jest praca w małych grupach, nie większych niż 20-osobowe. Przy dużej liczbie katechizowanych i odpowiednio znacznej liczbie grup wymaga to zaangażowania kompetentnych animatorów z ruchów religijnych, stowarzyszeń i wspólnot. Owszem, jest to potrzeba organizacyjna, jednakże również - a pewnie przede wszystkim potrzeba programowa. Rzecz w tym, by katechizowani mieli sposobność rozpoznać istotny wymiar życia Kościoła i parafii: wymiar wspólnotowy. Jednym z zadań katechezy jest przecież wychowanie do życia wspólnotowego. Owych animatorów na potrzeby katechezy sakramentalnej nie uda się zorganizować i przygotować ad hoc, bez już rozwiniętego życia wspólnot i zespołów parafialnych. W ten sposób katecheza sakramentalna, zwłaszcza związana z bierzmowaniem, uwyraźnia potrzebę stałego budowania parafii jako wspólnoty wspólnot. Katecheza parafialna z wyraźnym odwołaniem do działających w parafii wspólnot niesie autentyzm treści, niesie świadectwo życia chrześcijańskiego. Ruchy dają na katechezie świadectwo życia modlitwy; zwłaszcza, że modlitwa jest wskazywana przez wiele ruchów jako ich charyzmat. Dają także świadectwo życia Kościoła. Pokazują czym jest Kościół i jak się doświadcza Kościoła w życiu osobistym. Pomagają przełamywać obraz Kościoła widzianego w wymiarach jednostronnie instytucjonalnych.

Po powrocie nauki religii do szkoły przygotowanie do bierzmowania stało się najważniejszym rodzajem katechezy parafialnej, także sposobem budowania więzi młodych z parafią. Ta katecheza inicjacyjna winna jeszcze mocniej niż dotąd akcentować potrzebę włączania się młodych ludzi w życie Kościoła, szczególnie w życie własnej parafii. Doświadczenia, na przykład archidiecezji krakowskiej, pokazują, że część młodzieży, która korzystała z dłuższego przygotowania do sakramentu, po bierzmowaniu kontynuuje bliższy związek z parafią, włączając się w różnorakie grupy, zespoły, ruchy religijne. Wiele znaczy wcześniejszy kontakt z przedstawicielami tych środowisk. Tak przyjęcie bierzmowania może się stać dla młodego człowieka wejściem w czas misji, świadectwa, apostolstwa. W istocie bierzmowanie kończy czas wtajemniczenia chrześcijań- 
skiego. Katecheza inicjacyjna ustępuje katechezie stałej. Ta również ma pomagać w dojrzewaniu młodego człowieka do uczestnictwa we wspólnocie Kościoła.

Wypada nieustannie szukać optymalnego modelu katechezy wtajemniczającej. Dziś w warunkach polskich ta katecheza zapewne musi wykorzystywać doświadczenia ewangelizacji, a może raczej postępować dopiero za nią.

\section{Zadania środowisk katechetycznych}

Wciąż szukamy coraz to lepszych rozwiązań. Wypada, by uwzględniały one dwie przesłanki. Pierwsza to założenie mówiące o integracji środowisk wychowawczo-katechetycznych: rodziny, parafii i szkoły. Druga z nich to założenie mówiące o zróżnicowanych celach i formach działania tych środowisk. Oba założenia wydają się niezbywalne: nie możemy z nich zrezygnować. Zatrzymajmy się przy obu. Przyglądając się miejscom katechezy, spróbujmy uwyraźnić ich zadania.

\section{Parafia}

Staje zatem jako sprawa otwarta takie budowanie współczesnego i przyszłego modelu parafii, który przewidywałby intensywną katechizację na jej terenie. Nie konkurującą, ale współpracującą z tym, co mamy dziś w szkole. Katecheza parafialna winna zwłaszcza przejmować realizację tych celów katechezy, w odniesieniu do których zauważa się największe deficyty pracy Kościoła w szkole. Jak wiemy, dotyczy to szczególnie wprowadzania młodego pokolenia w samą wspólnotę Kościoła oraz w jej życie sakramentalne. Ma katecheza także prowadzić do pogłębiania wiary zainicjowanej w rodzinie, choć przy znaczących dziś deficytach wychowawczej i religijnej funkcji rodziny to inicjowanie wiary faktycznie - tak bywa - dokonuje się dopiero w szkole bądź w parafii. Również tego zadania parafia nie może nie zauważać.

Nieodzowne jest zatem dopracowanie modelu parafialnej katechezy dzieci i młodzieży traktowanej jako komplementarna wobec katechezy szkolnej, ale także - już dodajmy - wobec katechezy rodzinnej. Rozwiązaniem najszczęśliwszym z możliwych jest wprowadzenie bądź rozwinięcie katechezy sakramentalnej, jednakże ta - rozumiana jako przygotowanie do przyjęcia sakramentów i utrwalanie owoców ich przyjęcia - wymaga jakiegoś, tymczasem mało doprecyzowanego, dopełnienia. Wciąż nie jest parafialnie zagospodarowany okres życia dzieci przypadający na klasy IV-VI szkoły podstawowej. Miałby to być okres mistagogii przedłużający wcześniej proponowaną tematykę. Słyszy się propozycje, by katecheza parafialna $\mathrm{w}$ okresie gimnazjalnym niosła tematy związane $\mathrm{z}$ historią zbawienia. Jednakże te treści dobrze pasują do katechezy w szkole i tam mogłyby się śmiało znaleźć. Parafii warto wówczas przypisać zadanie organizowania nabożeństw biblijnych i innych form modlitwy. 
Formułowana jest propozycja takiego modelu zajęć katechetycznych, by jedna godzina w tygodniu odbywała się w szkole, druga w parafii. I miałyby się różnić charakterem; odmiennym rozłożeniem akcentów. W szkole dominowałby przekaz wiedzy otwierający na doświadczenie wiary; w parafii pogłębianie wiary oraz wprowadzanie w życie sakramentalne (sakramenty inicjacji chrześcijańskiej) i wspólnotę Kościoła. Rozwiązanie tego rodzaju mogłoby objąć uczniów szkół ponadpodstawowych, zatem od poziomu gimnazjalnego poczynając. Dzieci młodsze pozostałyby w szkole (wyjątkiem byłby okres bardziej intensywnych przygotowań do I Komunii św., realizowanych tradycyjnie w parafii), by nie stawiać rodziców w kłopotliwej konieczności przyprowadzania dzieci na katechezę w parafii.

Wypada, by organizacyjnymi podmiotami katechezy parafialnej otwierającej dzieci i młodzież na życie sakramentalne we wspólnocie Kościoła były różnorakie ruchy, stowarzyszenia i wspólnoty religijne. One same, jeśli dobrze pracują, mogą być świadectwem eklezjalnego wymiaru życia sakramentalnego. Ich przedstawiciele mogą odegrać - $\mathrm{i}$ faktycznie $\mathrm{w}$ wielu parafiach $\mathrm{z}$ powodzeniem odgrywają - dużą rolę w katechezie na terenie parafii, zwłaszcza na etapie przygotowania do bierzmowania.

\section{Rodzice}

Wypracowując model parafialnej katechezy sakramentalnej, wypada uwzględnić dwie przesłanki: (1) Szczególnymi adresatami parafialnej katechezy winni być dorośli; wszak tych nie spotykamy już w szkolnych ławkach. (2) Pierwszymi katechetami, jak i pierwszymi wychowawcami dla swych dzieci, mają być rodzice. $\mathrm{Z}$ owych przesłanek wynika pilna potrzeba rozwijania katechezy dorosłych, zwłaszcza rodziców: wyposażanie ich w wiedzę religijną, ale również motywowanie, by wobec swoich dzieci zechcieli być dobrymi katechetami. Znów staje znaczenie katechezy sakramentalnej. Dla katechezy rodziców należałoby bowiem wykorzystywać zwłaszcza okres rodzinnych przygotowań do przyjęcia przez młode pokolenie sakramentów inicjacji chrześcijańskiej. Warto też myśleć o drogach katechezy systematycznej dorosłych. Jest sporo - choć w istocie na niewielką skalę - doświadczeń w tym zakresie. Istotne jest tu danie rodzicom intelektualnych fundamentów ich wiary. Praca ściśle katechetyczna winna być prowadzona $\mathrm{w}$ stosunkowo niewielkich grupach. Wypada stosować metody aktywizujące; stroniąc od pompatycznych - zbliżonych charakterem do kazania - prelekcji.

Katecheza rodziców winna odnaleźć wyraziste umocowanie w rocie ich przysięgi małżeńskiej. Wszak składali tam obietnicę, że dzieci wychowają po katolicku. Teraz Kościół ma prawo wymagać realizacji tej obietnicy, ale i powinien rodzicom pomóc $w$ jej spełnieniu. Właśnie przez solidną katechezę dorosłych. Także przez pedagogizację rodziców. 
Stymulowanie katechetycznej roli rodziców jest dziś tym ważniejsze, że w sytuacji szkolnej nauki religii ich dzieci rodzice poczuli się zdyspensowani z troski o katechezę, co było udziałem wielu rodziców przy modelu katechezy w punktach katechetycznych. Rodzice przyprowadzali dzieci na zajęcia, często sami dyskretnie w nich uczestnicząc. Także pomagali duszpasterzom w utrzymaniu obiektów katechetycznych. Dziś upowszechniło się przekonanie, że pomoc rodziców dla katechetycznej pracy Kościoła straciła uzasadnienie. Redukuje się kontakt rodziców z katechetami, zanika troska o materialne potrzeby pracy katechetycznej. Co więcej, rozszerza się przekonanie, że teraz szkoła zdolna jest przejąć pełną odpowiedzialność za wychowanie dziecka. Bo jest to już szkoła nowa, obecnością w niej Kościoła wychowawczo dowartościowana. Na tym tle nie dość podkreślania, że to od pracy z rodzicami - osobliwie $\mathrm{w}$ ramach katechezy sakramentalnej ich dzieci - winna się rozpoczynać posługa Kościoła wobec najmłodszego pokolenia. Niejednokrotnie włożyć trzeba sporo wysiłku, by pomóc rodzicom w dojściu do przekonania, iż miejscem właściwym dla katechezy sakramentalnej ich dzieci jest własna parafia. Nie eksponować tu wymogów formalnych władzy diecezjalnej. Podkreślać, że w istocie chodzi o formację dziecka w miejscu i w tej przestrzeni społecznej, w której są sami rodzice. Wskazywać, że obecność dziecka w szkole jest w istocie przelotna, najwyżej kilkuletnia. Obecność w parafii ma wyraźnie dalszą perspektywę. Przy tym wypada, by cała rodzina budowała kontakt $\mathrm{z}$ własną parafią.

\section{Szkoła}

Słyszymy całkiem poważne głosy podnoszące celowość takiego przemodelowania formy obecności Kościoła w szkole, by zajęcia z dziećmi i młodzieżą stały się klasycznymi lekcjami religii (którymi nota bene nie uznają za właściwe zajmować się katechetyczne dokumenty Kościoła powszechnego), rezygnując ze swego katechetycznego charakteru. Za takim modelem obecności Kościoła w szkole opowiada się znaczna część naszego społeczeństwa. Co więcej, w lekcjach religii - jak widzieliśmy - upatruje się szansę na przedstawienie uczniom różnych światowych religii.

Ograniczenie się w szkole do lekcji religii o charakterze przede wszystkim kulturowym (czyli zorganizowanie materiału dydaktycznego wokół skądinąd ważnych zagadnień dotyczących wkładu chrześcijaństwa w kulturę polską i europejską) oznaczałoby wycofanie się z głoszenia kerygmatu i otwierania młodego pokolenia na perspektywę wiary. W skrajnych przypadkach mielibyśmy do czynienia z desakralizacją przekazywanych treści.

Z czasem mogłoby się okazać, że przy lekcjach religii wolnych od katechetycznych znaczeń nie jest w ogóle potrzebna misja kanoniczna. Byłoby to równoznaczne z faktycznym wycofaniem się Kościoła ze szkoły. Lekcje religii już 
bardzo łatwo mogłyby się stać zajęciami $\mathrm{z}$ religioznawstwa. $\mathrm{Z}$ całą pewnością nie tędy droga.

\section{Słowo podsumowania}

Po z górą dwudziestoleciu zbierania szkolnych, ale i parafialnych, doświadczeń czekają nas zadania poważne. Chodzi o przemodelowanie tego, co dzieje się $\mathrm{w}$ szkole oraz modelowanie tego, czego jeszcze $\mathrm{w}$ istocie nie ma w parafii bądź jest na nie do końca satysfakcjonującą miarę. W istocie nieodzowne jest mocne wzbogacenie parafii o wymiar katechetyczny. II Synod Plenarny Kościoła w Polsce wskazywał, że szkolne nauczanie religii ma znaleźć dopełnienie w katechezie parafialnej. Ten kierunek projektowania i działania jest dziś dla nas zobowiązujący. Co więcej, wymaga wzmocnienia. To raczej szkolne nauczanie religii winno być traktowane jako działanie dopełniające katechezę inicjacyjną, dla której miejscem właściwym jest parafia. Przecież to ona stanowi podstawowe środowisko wtajemniczenia chrześcijańskiego (DOK, n. 257) ${ }^{28}$. Wypada przy tym myśleć o integracji środowisk wychowania katechetycznego. Rodzina ma dawać podstawy kontaktu z Bogiem, inicjować życie wiary. Parafia ma dawać wtajemniczenie w życie sakramentalne i wspólnotowe zarazem. Szkoła ma dawać dojrzałość rozumienia. Potrzebne jest wszystko, w tym zwłaszcza uwyraźnienie wspólnotowego charakteru sakramentów inicjacji. Potrzebny jest także trudno ukryć - katecheta. Podejmując posługę towarzyszenia dziecku w jego sakramentalnym wtajemniczeniu winien sam, nigdy dość podkreślać, być świadkiem modlitwy i żyć sakramentami. Harmonia modlitwy, życia sakramentalnego i życia codziennego, która katechizowani będa mogli dostrzec u katechety, stanowi potężny środek, który może urzeczywistnić w nich takowa postawę oraz wyzwolić pragnienie wewnętrznej przemiany. Osoby katechizowane moga wzrastać $w$ wierze tylko $z$ katecheta, który sam idzie droga wiary ${ }^{29}$.

Obok dobrze znanego, wspaniałego, wielce obiecującego stwierdzenia, iż droga Kościoła jest człowiek (niosącego wszak - dodajmy - pewne ryzyko apoteozowania człowieka) wypada postawić - to już w duchu Benedykta XVI - tezę, że droga Kościoła jest miłość. Teza ta powinna być dla młodego pokolenia przekonująca; przekonująca tym bardziej, im w naszych rodzinach jest mniej miłości, mniej wychowawczego zatroskania. Na tej tezie wypada opierać pracę Kościoła z młodzieżą - także pracę katechetyczną. Tak Kościół ma szansę stać się dla wielu młodych swego rodzaju „rodziną zastępczą”. Trudno nie zaakcentować, że $\mathrm{z}$ projektem tym wprost koresponduje hasło na rok duszpasterski 2011-2012

\footnotetext{
${ }^{28}$ Zob. S. D z i e k o ń s k i: Katecheza inicjacyjna w Polsce - rzeczywistość i oczekiwania. W: Funkcja inicjacyjna katechezy w Kościele wspótczesnym. Red. K. K a n t o w s k i. Szczecin 2007 s. $101 \mathrm{n}$.

${ }^{29}$ J. S z p e t: Inicjacyjna funkcja katechezy, dz. cyt., s. $63 \mathrm{n}$.
} 
„Kościół naszym domem”. Stawia to zwłaszcza przed parafią oczywiste zadania. Mocno w niej zakorzenieni katecheci winni młodemu pokoleniu ów dom z entuzjazmem swej wiary pokazywać. Jako katecheci już w owym wygodnym dla nich domu mieszkający mają dzieci i młodzież do tego domu zapraszać. By młode pokolenie żyło życiem Kościoła, zatem życiem wspólnotowym i życiem sakramentalnym. 